\title{
Populasjonssykluser hos hare - drevet av rovdyr og spesielt gaupe
}

\section{Dorothee Ehrich og Nigel G. Yoccoz}

Dorothee Ehrich (f. 1969) har PhD i biologi fra Ui0 og har siden 2007 jobbet ved UiT, hovedsakelig med trofiske interaksjoner og klimapåvirkning i tundraøkosystem.

Nigel G. Yoccoz (f. 1964) har PhD i økologisk statistikk fra Univ. i Lyon. Han har vært ansatt ved UiT siden 2003, hvor han arbeider med statistisk og matematisk modellering innen miljøforskning.

Snøskohare - og gaupesyklusene i det boreale Nord-Amerika er et av de best kjente eksempler på populasjonssykluser. Sammenlignet med andre sykliske arter har denne syklusen en relativ konstant periode på 9-10 år. Haretettheten varierer typisk 20-30 ganger mellom topp- og bunnår. Mye økologisk forskning har ved hjelp av forskjellige metoder forsøkt å avdekke årsakene til snøskoharesyklusene, også med imponerende storskala felteksperimenter. Predasjon er den viktigste syklusdriveren, og i tillegg til direkte dødelighet, kan også stress fra intens jakt fra rovdyr og matmangel $\mathbf{i}$ nedgangsfasen spille en rolle. Snøskoharen er en nøkkelart i det boreale økosystemet $\mathbf{i}$ Nord-Amerika og et viktig byttedyr ikke bare for gaupe, men også for mange andre predatorer som coyote, rødrev eller hubro. Gjennom direkte og indirekte interaksjoner $i$ næringsnettet påvirker snøskoharen dynamikken til store deler av økosystemet. Snøskoharen og den kanadiske gaupa er betydelig mindre enn de eurasiske hare- og gaupeartene, og bare de nordamerikanske artene har så klare og godt dokumenterte populasjonssykluser.

\section{Klassiske populasjonssykluser}

Populasjonssvingningene hos snøskohare og kanadisk gaupe i de boreale skogene i NordAmerika er et av de mest kjente eksemplene på populasjonssykluser og sterke relasjoner mellom byttedyr og rovdyr. Disse syklusene har vært kjent av pelsjegere i flere hundre år, og studert av økologer i over et århundre. Det at hare er jaktet på både for pels og mat, og at gaupejakt var en viktig næring på grunn av den verdifulle pelsen, kan ha bidratt til den prominente posisjonen disse syklusene har hatt i økologisk forskning. Men viktigst er det nok at disse syklusene er tydelige og regelmessige, og at de er godt dokumenterte på grunn- lag av svært lange tidsserier med fangststatistikk.

Den nordamerikanske haresyklusen har en relativt konstant syklusperiode på 9-10 år, mens det er stor variasjon i amplituden (det vil si forskjellen mellom bunnår og toppår). Noen ganger kan det oppstå «supertopper», hvor harene er så tallrike at det er beitespor overalt. Andre ganger kan toppene være så lave at de nesten ikke blir lagt merke til av folk flest. I det nordvestlige Canada varierte haretettheten 20-30 ganger mellom topp- og bunnår i perioden 1980-2012 (Krebs mfl. 2014), men syklusamplituder på over 100 ganger har vært observert. Tettheten i toppår var mellom $100 \mathrm{og}$ 


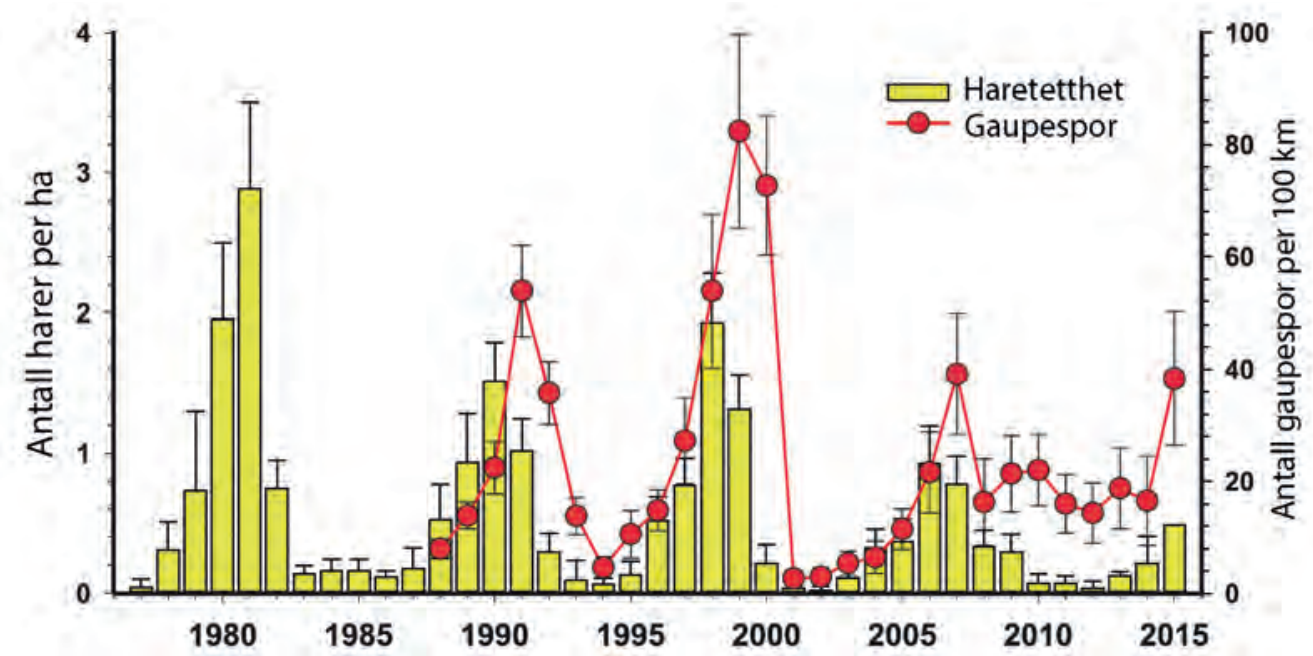

Figur 1. Hare- og gaupedynamikken på våren i Kluane-område i det nordvestlige Canada. Kurven for hare er basert på populasjonstettheter estimert fra levendefangst-data, mens gaupekurven er en tetthetsindeks basert på antall gaupespor på senvinteren. Man ser den systematiske tidsforsinkelsen mellom hare og gaupe som kjennetegner relasjonen mellom et byttedyr og en spesialisert predator (figur fra Boonstra mfl. 2016).

600 harer per $\mathrm{km}^{2}$, mens i bunnårene kan det være mindre enn 10 harer per $\mathrm{km}^{2}$. Dette er fortsatt en god del mer enn gjennomsnittet på fastlandet i Skandinavia (1-2 individer per $\mathrm{km}^{2}$; Angerbjörn og Flux 1995). Haresyklusen er asymmetrisk ved at oppgangen før toppen ofte skjer saktere (over 3-4 år) enn nedgangen etterpå (over 2-3 år). Etter nedgangen følger flere år med veldig lave haretall. Gaupesyklusen følger haredynamikken tett, med den typiske tidsforsinkelsen som kjennetegner relasjonen mellom et byttedyr og en spesialisert predator (figur 1).

Hare- og gaupesyklusene er ikke synkrone over det enormt store boreale Nord-Amerika. Det har vært en tendens til at svingningene sprer seg over kontinentet som en bølge som starter fra et senter i de nordlige delene av Saskatchewan og Manitoba (i Canada) og utvider seg derfra mot øst og vest. Dette har resultert i opp til fire års tidsforskjell mellom toppårene i forskjellige regioner. En mulig årsak til en sånn bølge er vandringer av predatorer som flytter bort fra områder hvor haretettheten har kollapset. I de sørligste delene av utbredelsen til snøskoharen er dynamikken mindre regelmessig og med lavere amplitude. En parallell til et slikt geografisk mønster ser vi i Skandinavia både hos smågnagere (se Soininen mfl. i denne utgaven av Naturen) og bjørkemålere (se Vindstad og Jepsen i denne utgaven av Naturen).

\section{Hare - og gaupearter med forskjellige tilpasninger og populasjonsdynamikk}

Den nordamerikanske snøskoharen (Lepus americanus) er betydelig mindre enn den eurasiske haren (Lepus timidus) som er vanlig i Norge. Voksne snøskoharer veier bare mellom 1,2 og 1,6 kg, mens de norske harene blir 2-5 $\mathrm{kg}$ tunge. Som navnet tilsier, har snøskoharen spesielt store poter (figur 2). Dette gjør det mulig for den å løpe oppå den løse snøen som er typisk for den boreale skogen i Nord-Amerika. Også den kanadiske gaupa (Lynx canadensis) er mindre enn vår eurasiske gaupeart Lynx lynx. Mens voksne kanadiske gauper veier mellom 8 og $11 \mathrm{~kg}$, blir våre gauper $18 \mathrm{~kg}$ eller mer. Med lav vekt, lange bein og store poter er også den kanadiske gaupa godt tilpasset bevegelse på løs snø (figur 3 ).

Den eurasiske haren finnes fra Irland og Skottland i vest og helt til Chukotka lengst øst i Sibir. Den finnes i boreal skog, tundra og høyfjell (f.eks. i Alpene). Populasjonsdyna- 


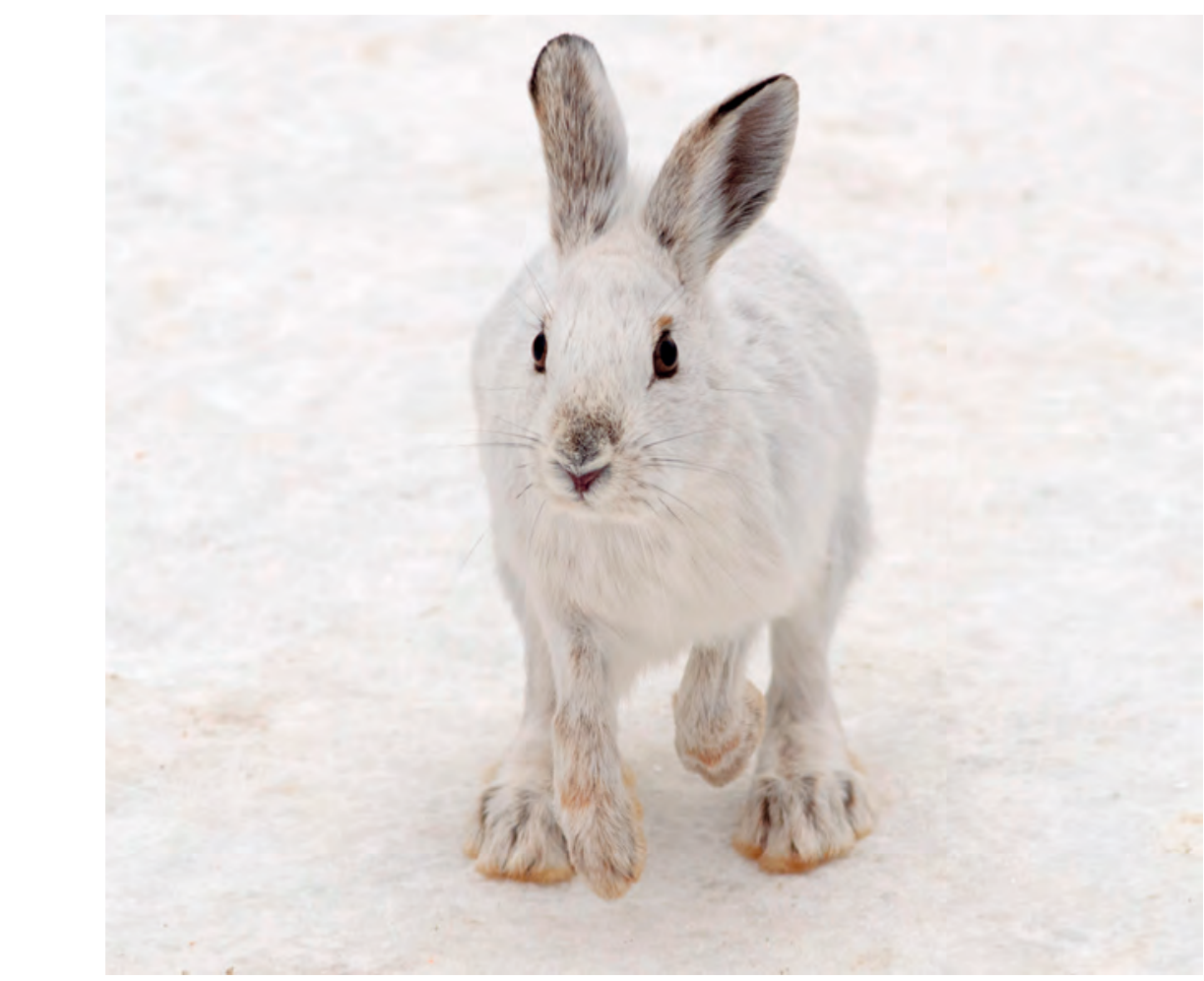

Figur 2. Snøskoharen i vinterpels, med de karakteristiske store potene. En hunn kan få opptil fire kull med mellom tre og fem unger $i$ hvert kull, $i$ løpet av en sommer. Harene lever $i$ gjennomsnitt ett år, og de fleste blir drept av rovdyr. På sommeren spiser de mye urter, gress og blader fra busker, mens de på vinteren først og fremst spiser kvister av dvergbjørk og vierbusker som stikker opp av snøen. Foto: Howard Sandlers, Shutterstock.

mikken til denne harearten er mye mer variabel enn hva gjelder snøskoharen (Newey mfl. 2007). Den eurasiske haren kan ha sykliske svingninger med en betydelig amplitude i deler av utbredelsesområdet. I Skottland har noen populasjoner statistisk signifikante sykluser med en periodelengde som i gjennomsnitt er ca. 9 år. Dog er sykluslengden mer variabel (4 til 15 år) og amplituden (opp til 10 ganger) vesentlig mindre enn for snøskoharesyklusen i Nord-Amerika. Andre populasjoner varierer mindre, og ikke systematisk. I Fennoskandia viser jaktstatistikk at hare kan ha populasjonssvingninger med en syklus på 3-4 år, spesielt i de nordlige delene av den boreale skogen. Denne periodelengden er den samme som for smågnagere i dette området. Det er derfor sannsynlig at harene i Norge utsettes for den samme «alternative byttedyr-mekanismen» som rypepopulasjonene her har vært preget av (se Henden mfl. i denne utgaven av Naturen).

Både i Canada og i Fennoskandia er relativ små, herbivore (dvs. plantespisende) pattedyr bestemmende for mye av mellomårs-dynamikken (dvs. forskjellen i antall og reproduksjon av artene mellom år) i det boreale økosystemet; i Canada er det snøskohare, mens i Fennoskandia er det smågnagere. Hvorfor det er forskjellige nøkkelarter i de to regioner, kan forklares av grunnleggende forskjeller i vinterklimaet (Boonstra mfl. 2016). I Canada er klimaet typisk kontinentalt med veldig kalde og tørre vintre, som gir et løst og grunt snødekke. I Fennoskandia derimot, er klimaet mer oseanisk - altså mildere og med mer nedbør - noe som gir et vesentlig tykkere og fastere snødekke. På grunn av denne forskjellen består bakkevegetasjonen i de fennoskandiske skogene mest av dvergbusker som blå- 


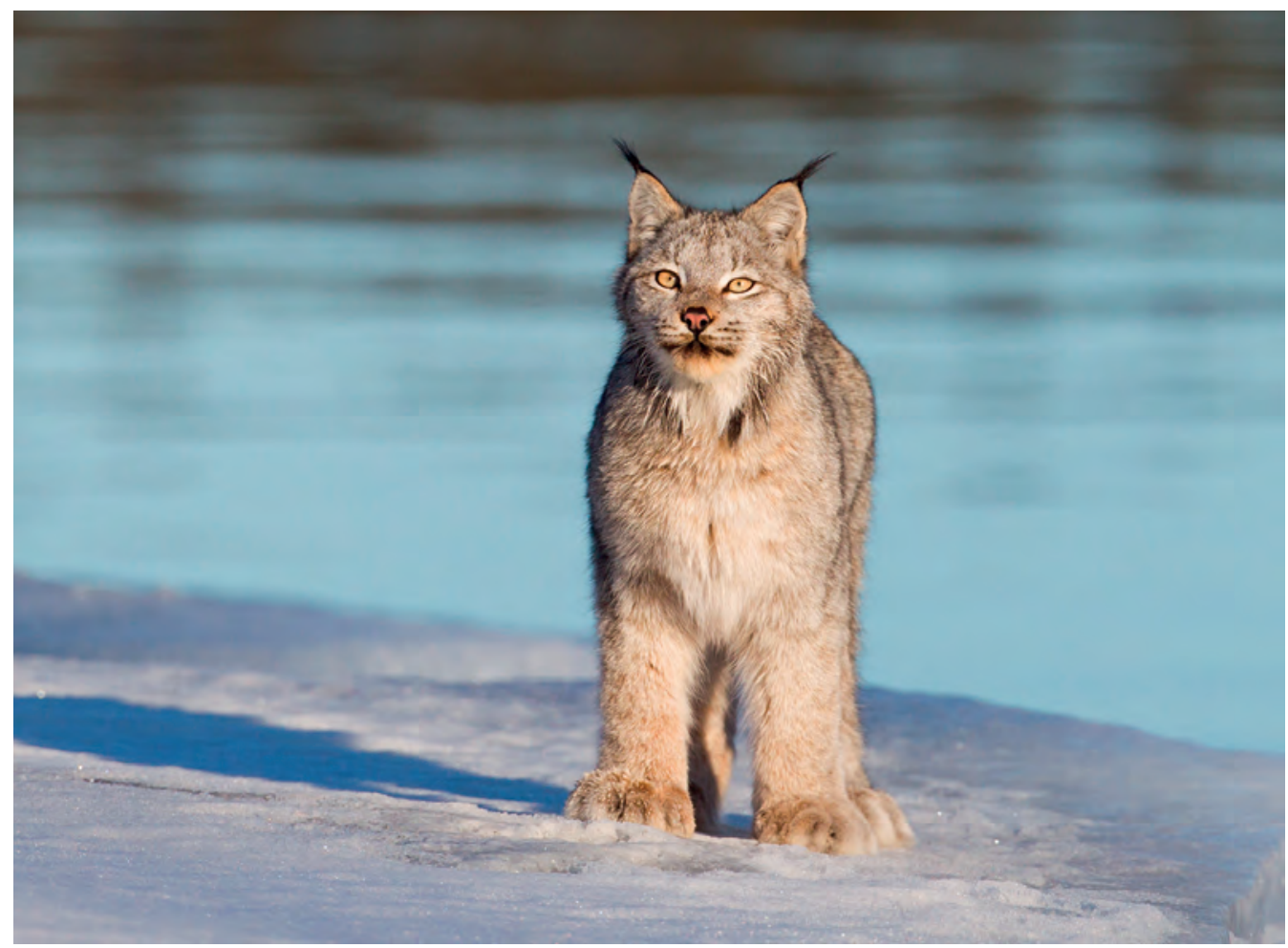

Figur 3. Kanadisk gaupe har store poter som tilpasning til å bevege seg på løs snø. Foto: Jukka Jantunen, Shutterstock.

bær, tyttebær og krekling. Disse plantene tåler ikke mange kuldegrader og trenger å være under et tykt, isolerende snødekke om vinteren. I Canada derimot vokser det mer høyvokste busker - krattdannende vier og dvergbjørk - som stikker ut av snødekket og som tåler den kalde lufta. Disse buskene er vintermaten til snøskoharen i Canada, mens dvergbuskene (særlig blåbær) er både god og tilgjengelig mat for smågnagere som lever på bunnen av snødekket i Fennoskandia. De forskjellige dominerende herbivorene gir opphav til forskjellige sykluser med store ringvirkninger i de to boreale økosystemene; 3-4års syklus basert på smågnagere i Fennoskandia, og 9-10-års syklus basert på snøskohare i Canada.

En stor del av verdens boreale skoger finnes i Russland, og både eurasisk hare og gaupe er vanlige der. Den store eurasiske gaupa har både en bredere og geografisk mer varierende diett enn den nordamerikanske. Mens nordli- ge, eurasiske gauper spiser mye hare, men også reinsdyr, er små klovdyr som rådyr et stadig viktigere byttedyr mot sør. Dermed kan ikke dynamikken mellom hare og gaupe forventes å være så tett relatert. Data på dynamikken til hare - og gaupepopulasjoner i Russland har ganske variabel kvalitet. Men den informasjonen som finnes, tyder på at gaupepopulasjonene fluktuerer med en faktor på mindre enn 10 mellom årene (ofte bare med en faktor på 24), og det er ingen regelmessighet (dvs. syklus) i svingningene i de fleste regionene. Harepopulasjonen varierer generelt mye, med uregelmessige toppår som kan ha svært høye tettheter. Men i noen områder, spesielt i Jakutia i Øst-Sibir, hvor klimaet er veldig kaldt og kontinentalt og landskapet ikke så flatt og myrlendt som lengre vest, viser pelsstatistikken gaupesvingninger med en betydelig amplitude og en syklusperiode på omtrent 10 år (Matyushkin 2003). Også harene i de Jakutiske boreale skogene har klare 10-12-års sykluser. 


\section{Haresyklusen i økologiens historie}

$\varnothing k o l o g i$ er en relativt ny vitenskapelig disiplin, men noen problemstillinger har vært debatterte $\mathrm{i}$ over hundre år. En av de mest langvarige debattene har dreid seg om «naturen er i balanse» - det vil si om populasjoner og økosystem er regulert til å være i likevekt med miljøet. I 1933 skrev A. J. Nicholson i klassikeren The balance of animal populations at «it appears to be usual at present to deny the existence of the 'balance of nature'». Dette reflekterte at mange økologer mente at dyrepopulasjoner var mest styrt av tilfeldige faktorer som for eksempel været. Nicholson var sterkt uenig i dette og hans artikkel var viktig for å skifte debatten i retning av at populasjoner var i en likevektstilstand, mest regulert av interaksjoner med andre arter - som beiteplanter/byttedyr, predatorer eller parasitter. I denne sammenheng var det interessant at Charles Elton, en av de viktigste økologene i forrige århundre, gjenoppdaget snøskoharesyklusen som faktisk allerede var beskrevet i flere bøker (Hewitt 1921 og Seton 1911). Spørsmålet var om haresyklusen var en konsekvens av en interaksjon mellom snøskohare og en annen biologisk faktor. Elton trodde at denne faktoren var sykdom, blant annet fordi Nicholson hadde vist med en matematisk modell at populasjonssykluser kunne oppstå i interaksjonen mellom parasitt og vert. Elton bidro til at det fra 1931 til slutten av 1940-tallet ble gjort systematisk overvåking av harepopulasjoner over store deler av Nord-Amerika. Dette skjedde med hjelp av flere hundre observatører - dermed et slags folkeforskningsprosjekt lenge før dette ble et eget felt i økologi. Dessverre kunne man ikke på bakgrunn av overvåkningsdata påvise hva som drev haresvingningene, selv om fokus hadde gått fra sykdom til predasjon og mangel på mat.

Hare- og gaupesyklusen har spilt en viktig rolle for utviklingen av flere tilnærminger $\mathrm{i}$ $ø$ kologisk forskning. Den har blitt brukt som et eksempel for å utvikle matematiske modeller for interaksjoner mellom rovdyr og byttedyr, og statistiske metoder for å analysere populasjonstidsserier (Stenseth mfl. 1997).
Haresyklusen har også spilt en viktig rolle i $ø$ kologi, fordi de nyere studiene drevet av Charles Krebs viser hvor viktig, men samtidig vanskelig, det kan være å kombinere eksperimentelle og observasjonelle studier for å løse en økologisk gåte.

\section{Nærmere driverne av haresyklusen gjennom storskala eksperimenter}

I 1976 startet Charles Krebs et langvarig forskningsprogram i Kluane (regionen Yukon i det nordvestlige Canada) for å avdekke hva som driver snøskoharesyklusen og ringvirkningene som den har på det boreale næringsnettet. På dette tidspunktet var man ganske enige i hvilke økologiske prosesser som kunne drive syklusene gjennom forsinket tetthetsavhengighet (se Vindstad og Jepsen i denne utgaven av Naturen). Krebs har alltid vært klar på at eksperimenter er nødvendige for å forstå årsakssammenhenger. Dette gjelder også for $ø$ kologiske fenomener som utspiller seg på stor skala i rom og tid - selv om dette selvfølgelig innebærer praktiske og ressursmessige utfordringer. På dette grunnlaget kunne man også bestemme designet på et storskala eksperiment som mangler sidestykke i boreal økologi. Krebs og kolleger har nylig publisert en artikkel hvor de oppsummerer resultatene fra disse eksperimentene og andre studier på hva som driver haresyklusen (Krebs mfl. 2018). Vi baserer mye av de følgende avsnittene på denne artikkelen.

Kluane-eksperimentet og assosierte observasjonsstudier fokuserte i starten på fire hypoteser: 1) overbeiting på vinteren fører til redusert mattilgang over flere vintre etter et toppår, fordi matplantene trenger lang tid for gjenvekst; 2) overbeiting forandrer kvaliteten på matplantene, fordi beiting fører til økt produksjon av antibeitestoffer som er skadelige for harene; 3) predasjon fører til vekst av rovdyrpopulasjoner, som dermed fører til økt predasjon i årene etter toppen; 4) en kombinasjonen av matmangel og predasjon er nødvendig for gi populasjonssyklus.

I eksperimentet ble både mattilgang og predasjon manipulert faktorialt på repliserte for- 


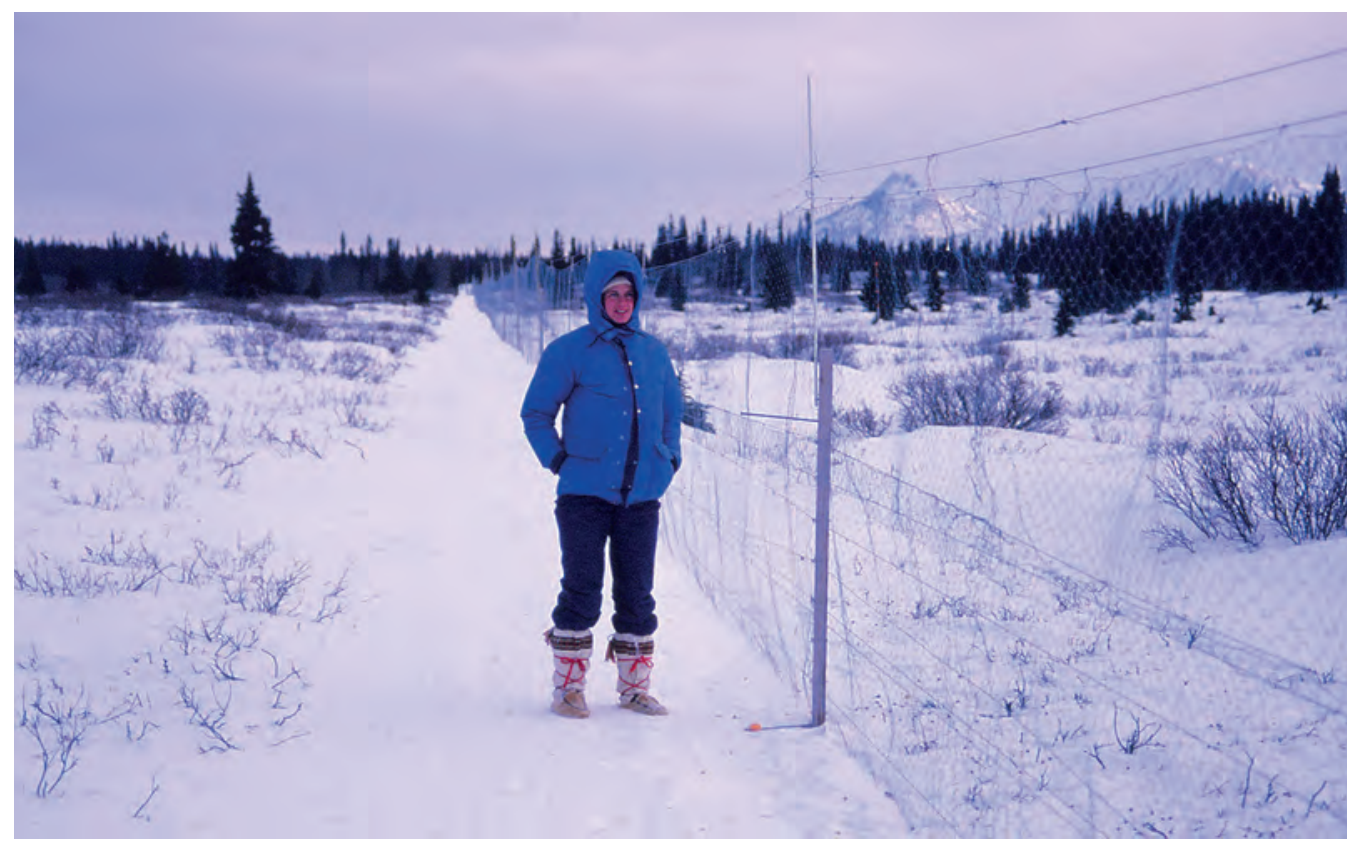

Figur 4. Gjerde rundt et av forsøksfeltene i Kluane, for å redusere predasjon. Man ser også kvister fra dvergbjørk og vier som stikker opp av snøen og som utgjør vintermaten til snøskoharen. Foto: Charles Krebs.

søksfelt på hele $1 \mathrm{~km}^{2}$. De viktigste rovdyrene som gaupe og coyote ble stengt ute ved å sette opp et elektrisk gjerde rundt en kvadratkilometer av borealskog. Dette gjerdet ble holdt ved like over en hel haresyklus, til tross for at grizzlybjørn og elg av og til skapte trøbbel (figur 4). Effekten av mattilgangen på vinteren ble testet ved å gi harene kaninfôr, ekstra tilgang på bark fra trær som ble felt, eller ved å gjødsle skogen for å øke produksjonen av beiteplanter. I oppgangsfasen og i toppåret førte økt mattilgang til høyere tettheter enn i kontrollområdene, men det stoppet ikke nedgangen av populasjonen etter toppåret. Dermed var ikke matmangel - iallfall ikke alene - årsaken til nedgangen (hypotese 1). Effekten av matkvalitet og antibeitestoffer (hypotese 2) var vanskeligere å teste, men målinger viste at konsentrasjonen av fenoler faktisk ble lavere $\mathrm{i}$ årene med høye haretettheter, noe som ikke tydet på at dette kunne bidra til nedgangen i bestanden. Kombinasjonen av økt mattilgang fra kaninfôr og redusert predasjon hadde den største effekten på haren. I toppåret var tettheten 11 ganger høyere som en følge av denne kombi- nasjonsbehandlingen, enn i kontrollområdene, og overlevelsen (målt med radiotelemetri) $\mathrm{i}$ nedgangsfasen var betydelig høyere enn for de andre behandlingene. Redusert predasjon uten økt mattilgang ga også økt overlevelse sammenlignet med kontrollfeltene. Dermed bekreftet eksperimentene i Kluane at predasjon var den viktigste driveren av syklusen (hypotese 3), men effekten av kombinasjonen av redusert predasjon og fôring viste at det var en interaksjon mellom predasjon og matmangel $\mathrm{i}$ nedgangsfasen (hypotese 4).

Et aspekt som fremdeles ikke kunne forklares var de store forskjellene i harenes reproduksjon i de forskjellige fasene av syklusen. To år før toppen var nådd avtok reproduksjonen. Færre hunner ble gravide; de fikk bare to kull i løpet av sommeren istedenfor fire, og kullene ble mindre. I gjennomsnitt tilsvarte dette en nedgang fra maksimalt 18,9 unger per år i starten av økningsfasen, til 6,9 i nedgangsfasen. Dette kunne ikke forklares av matmangel. Målinger av stresshormoner (kortisol) viste at harene var mer stresset i somrene med høye haretettheter og høy rovdyraktivitet, og økt 
stressnivå hos mødre førte til lavere reproduksjon. Det som var virkelig interessant var at stresseffekten hos mødrene ble overført til ungene, som også hadde forhøyede nivåer av stresshormoner. Stress fra høy rovdyraktivitet hadde dermed en negativ påvirkning på harenes reproduksjon over flere generasjoner, gjennom en såkalt maternell effekt. Dette virker forsterkende på predasjonseffekten og kan forklare at lengden på lavfasen i syklusen kan vare fra 2 til 5 år. Hittil har ingen studier tydet på at sykdommer eller parasitter driver haresyklusen, men noen observasjoner åpner for muligheten for at harer med mange parasitter kan bli mer utsatt for predasjon.

\section{Snøskohare som nøkkelart i det boreale økosystemet}

Charles Krebs beskriver snøskoharesyklusen som et pulserende hjerte i det boreale økosystemet i Nord-Amerika (Krebs 2011). Harene er et viktig byttedyr for nesten alle predatorer $\mathrm{i}$ dette systemet. Den kanadiske gaupa er den mest spesialiserte harejegeren, men også hønsehauk, ugler, coyote, rødrev, jerv og ulv jakter hare (figur 5). Til og med to ekornarter spiser mange hareunger. Effekten av fluktuasjonene i harepopulasjonen på predatorpopulasjonene varierer fra art til art, med naturligvis den største effekten på gaupa. Men fordi alle predatorartene responderer i noen grad, har haresyklusene effekter på den samlede predatorbiomassen $\mathrm{i}$ næringsnettet. Haresyklusene har også betydelige effekter på vegetasjonen. Siden snøskohare stort sett er en buskspiser, viser det seg at vierkratt blir særlig sterkt påvirket når haretettheten er høy. Seton (1911) beskrev snøskoharen som en pest som kunne fjerne bark og drepe store mengder vier.

\section{Vil klimaendringene påvirke snøskoharesyklusen?}

Det finnes per i dag lite kunnskap om hvordan klimaendringene kommer å påvirke snøskoharesyklusen. Men overvåkning som Krebs og kolleger fremdeles gjennomfører i Kluane viser at økosystemet er i endring. Siden år 2000 har mår og røyskatt blitt mye vanligere, og puma har kolonisert området. Man vet imidlertid ikke om dette skyldes klimaendringer eller andre endringer i økosystemet. Sommertemperaturen i Kluane har økt noe mot slutten av forrige århundre, mens vintrene viser store mellomårs-variasjoner i gjennomsnittstemperatur, dog uten noen klar trend (Myers-Smith og Hik 2018). Over de siste 20 årene har amplituden i haresyklusene blitt mindre. Det er mest sannsynlig at den lavere amplituden skyldes forandringene i rovdyrsamfunnet, med mer generalistpredatorer og/eller forandringer i jakteffektiviteten til gaupe og coyote. Kanskje dette kan ha noe med forandrede snøforhold å gjøre? Kortere vintre eller hardere snø kan gjøre det lettere for rovdyr å ta harene.

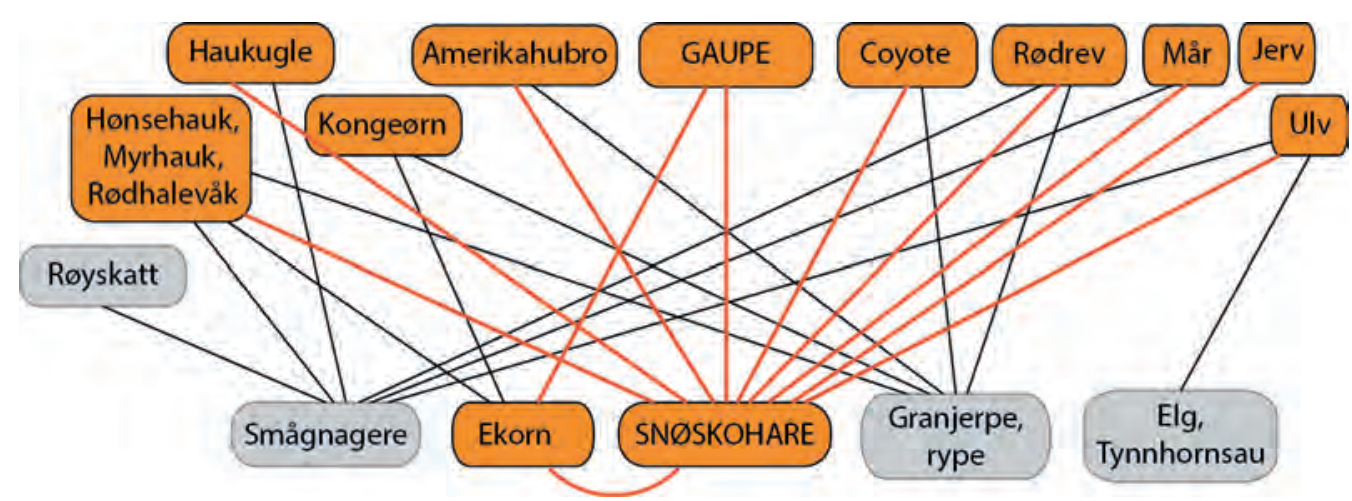

Figur 5. Skjematisk representasjon av næringsnettet $i$ et nord-amerikansk borealt økosystem. Snøskoharen er en nøkkelart, og gaupe er dens viktigste predator. Alle rovdyr som spiser hare er fremhevet $i$ oransje, men også mange andre arter kan bli påvirket indirekte av haresyklusen (figur tegnet etter Krebs mfl. 2018). 
I fremtiden kan senere snøfall på høsten og tidligere snøsmelting på våren bli til et problem for harene. I den hvite vinterpelsen er harene godt kamuflerte i et snødekket landskap, men er derimot veldig godt synlige for rovdyr på barmark. Pelsskifte hos snøskohare har blitt undersøkt i den sørlige delen av utbredelsesområdet, i Montana (USA) over flere år (Zimova mfl. 2014). På våren skiftet harene til brun pels tidligere når snøen smeltet tidligere, mens på høsten var de mindre fleksible, noe som tyder på at pelsskiftet på høsten er styrt av lyset. Når harene allerede er hvite mens snøen kommer stadig senere på høsten, blir de ekstra utsatte for predasjon. Studien fra Montana viste at overlevelsen i denne tiden kan gå ned med hele $7 \%$ per ekstra uke uten snødekke. En tilsvarende negativ effekt av korte vintre har blitt vist for hare i Norge (Pedersen mfl. 2017). Derfor, hvis lengden på vintersesongen blir vesentlig kortere i de boreale skogene, er hverken trugeføtter eller tidlig hvit pelsfarge lenger gode tilpasninger for snøskoharene. I så fall kan dette få stor betydning for om vi også i framtiden vil kunne oppleve de klassiske rovdyr-byttedyrsyklusene i de boreale skogene.

\section{Referanser og videre lesning}

Angerbjörn A og Flux J. 1995. Lepus timidus. Mammalian Species 495: 1-11.

Boonstra R, Andreassen HP, Boutin S, Husek J, Ims RA, Krebs CJ, Skarpe C og Wabakken P. 2016. Why Do the Boreal Forest Ecosystems of Northwestern Europe Differ from Those of Western North America? BioScience 66: 722-734. doi.org/10.1093/biosci/biw080.

Hewitt CG. 1921. The Conservation of the Wild Life of Canada. Charles Scribner's Sons.

Krebs CJ. 2011. Of lemmings and snowshoe hares: the ecology of northern Canada. Proceedings of the Royal Society B: 278: 481489. doi.org/10.1098/rspb.2010.1992.

Krebs CJ, Bryant J, O’Donoghue M, Kielland K, Doyle F, Carriere S, DiFolco D, Berg N, Boonstra R, Boutin S, Kenney AJ, Reid DG, Bodony K, Putera J, Timm HK, Bruke T, Maier JAK og Golden H. 2014. What factors determine cyclic amplitude in the snowshoe hare (Lepus americanus) cycle? Canadian Journal of Zoology 92: 1039-1048. dx.doi.org/10.1139/cjz-2014-0159.

Krebs CJ, Boonstra R og Boutin S. 2018. Using experimentation to understand the 10 -year snowshoe hare cycle in the boreal forest of North America. Journal of Animal Ecology 2018: 87-100. DOI: 10.1111/13652656.12720 .

Matyushkin YeN og Vaisfeld MA. 2003. The lynx. Regional features of ecology, use and protection. Nauka, Moskva.

Myers-Smith I og Hik D. 2018. Climate warming as a driver of tundra shrubline advance. Journal of Ecology 106: 547-560. DOI: 10.1111/1365-2656.12720.

Newey ST, Willebrand DT, Haydon F, Dahl F, Aebischer NJ, Smith AA og Thirgood SJ. 2007. Do mountain hare populations cycle? Oikos 116: 1547-1557. Doi.org/10.1111/ j.2007.0030-1299.15868.x.

Nicholson AJ. 1933. The balance of animal populations. Journal of Animal Ecology 2 (Suppl. 1): 132-178. DOI: 10.2307/954.

Pedersen S, Odden M og Pedersen HC. 2017. Climate change induced molting mismatch? Mountain hare abundance reduced by duration of snow cover and predation abundance. Ecosphere 8: e01722. 10.1002/ ecs2.1722.

Seton ET. 1911. The Arctic prairies. Charles Scribner's Sons, New York, USA.

Stenseth NC, Falck W, Bjørnstad ON og Krebs CJ. 1997. Population regulation in snowshoe hare and Canadian lynx: Asymmetric food web configurations between hare and lynx. Proceedings of the National Academy of Sciences USA 94: 5147-5152. doi.org/ 10.1073/pnas.94.10.5147

Zimova M, Mills LS, Lukacs PM og Mitchell MS. 2014 Snowshoe hares display limited phenotypic plasticity to mismatch in seasonal camouflage. Proceedings of the Royal Society of London B: 281: 20140029. dx.doi.org/10.1098/rspb.2014.0029. 